\title{
Nilai Karakter Mandiri Tokoh Dalam Novel Sepasang Angsa Putih Untuk Palupi : Sebuah Pendekatan Pragmatik Sastra
}

\author{
Tia Sartika*, Een Nurhasanah, Ferina Meliasanti \\ Universitas Singaperbangsa Karawang, Indonesia \\ *Coresponding Author: tiasartika97@gmail.com
}

Article History:

Received 2021-12-28

Revised 2022-02-03

Accepted 2022-03-01

DOI:

10.31949/educatio.v8i1.1844

\begin{abstract}
The purpose of this research is to (1) describe the intrinitarian elements found in the novel a Sepasang Angsa Putih Untuk. Palupi by Marliana Kuswanti, (2) the independent values contained in the novel sepasang angsa putih untuk palupi by marliana kuswanti, (3) describe the use of the novel as teaching material. The study USES a qualitative approach with a descriptive analysis method. Research subjects are the identities of Sepasang Angsa Putih Untuk Palupi by Marliana Kuswanti and the subject of research which is intrinsic elements and independent values. The method of collecting data used was a library study. Research shows as (1) an intrinitarian element in the novel Sepasang Angsa Putih Untuk. Palupi by Marliana Kuswanti, covering subjects, patterns, Settings, language styles, and addresses, (2) the independent value in the novel Sepasang Angsa Putih Untuk Palupi by Marliana Kuswanti covers, the independent emotions, the independent economy, the independent intellectual, the independent social(3) an analysis of Sepasang Angsa Putib Untuk Palupi by marliana kuswanti is made into teaching materials by making the proposed learning plan (RPP) for analysis of instrinsik elements and the book's text code.
\end{abstract}

Keywords: novels; intrinsic elements; independent values

\begin{abstract}
Abstrak
Tujuan dari penelitian ini adalah untuk (1) menguraikan unsur intrinsik yang terdapat dalam novel Sepasang Angsa Putih Untuk Palupi Karya Marliana Kuswanti, (2) dan nilai mandiri yang terdapat dalam novel Sepasang Angsa Putih Untuk Palupi Karya Marliana Kuswanti, (3) mendeskripsikan pemanfaatan novel sebagai materi ajar. Penelitian ini menggunakan pendekatan kualitatif dengan metode deskriptif analisis. Subjek penelitian adalah identitas novel Sepasang Angsa Putih Untuk Palupi Karya Marliana Kuswanti dan objek penelitian yaitu unsur intrinsik dan nilai mandiri. Teknik pengumpulan data yang digunakan yaitu studi pustaka. Hasil penelitian menunjukkan sebagai (1) unsur intrinsik dalam novel Sepasang Angsa Putih Untuk Palupi Karya Marliana Kuswanti, meliputi tema, alur, latar, penokohan, sudut pandang, gaya bahasa dan amanat, (2) nilai mandiri yang terdapat dalam novel Sepasang Angsa Putih Untuk Palupi Karya Marliana Kuswanti meliputi, nilai kemandirian emosi, nilai kemandirian ekonomi, nilai kemandirian intelektual, dan nilai kemandirian sosial, (3) hasil analisis novel Sepasang Angsa Putih Untuk Palupi Karya Marliana Kuswanti dijadikan materi ajar dengan membuat Rencana Pelaksanaan Pembelajaran (RPP) mengenai analisis unsur instrinsik dan kaidah teks novel.
\end{abstract}

Kata Kunci: novel; unsur intrinsik; nilai mandiri

\section{PENDAHULUAN}

Karya sastra merupakan suatu bukti gambaran dan hasil pemikiran seorang pengarang mengenai permasalahan yang terjadi dikehidupan manusia, baik itu berasal dari pengalaman pribadi maupun fenomena yang ada dalam lingkungan sekitar (Fitrianingrum, 2016). Karya sastra dapat diambil dari kehidupan bermasyarakat yang dapat memberi peserta didik gambaran tentang sebuah pemahaman yang belum mereka alami dalam hidupnya. Melalui pembelajaran sastra peserta.didik dapat menerapkan nilai-nilai positif yang terkandung di dalam kehidupan nyata. Karya sastra merupakan penggambaran cerita baik itu berupa fiksi maupun non-fiksi yang mampu meningkatkan imajinasi bagi para pembaca (Baron, 2020; Wicaksono, 2017). 
Karya sastra juga memiliki banyak bentuk yang semuanya mempunyai nilai-nilai positif bagi para penikmatnya. Banyak sekali manfaat yang bisa diperoleh dengan membaca karya sastra. Karya sastra juga tidak hanya dijadikan sebagai hiburan bagi para penikmatnya, bisa juga dijadikan untuk kegiatan sekolah pelajaran sekolah (Djuanda, 2014; Kusuma, 2018; Sukirman, 2021). Dalam karya sastra tentu saja tidak sembarang lahir dengan tanpa adanya nilai-nilai positif bagi para penikmatnya. Karya sastra selain membuat para penikmatnya senang, tetapi juga memiliki nilai-nilai positif didalamnya. Nilai positif ini hampir semua berkiblat pada gambarangambaran kehidupan manusia. Dalam sebuah karya sastra bukan hanya menyampaikan cerita yang menarik tetapi juga pesan positifnya harus tersampaikan kepada pembaca (Susilo et al, 2021).

Menambah pengetahuan dan pengalaman juga bisa didapatkan melalui membaca sebuah karya sastra. Sudah banyak pengarang yang menceritakan pengalaman pribadi maupun. pengalaman oranglain. Dengan membaca karya sastra pun dapat meningkatkan kemampuan analisis. Dalam hal ini biasanya di sekolah peserta didik diminta oleh guru mereka untuk menganalisis. sebuah karya sastra, bagi siswa yang terbiasa membaca karya sastra hal ini bukanlah sesuatu yang sulit untuk menganalisis sebuah karya sastra. Selain itu, maanfaat yang paling dirasakan oleh setiap pembaca yaitu dapat mempengaruhi pola pikir pembaca, karena cerita di dalamnya terdapat konflik dan klimaks melalui tokoh dalam cerita tersebut yang pastinya akan mempengaruhi pola pikir para pembaca.

Karya sastra juga memiliki banyak bentuk, salah satunya adalah novel. Novel sebagai salah satu karya sastra yang tidak jauh berbeda seperti cerita pendek. Membaca sebuah novel dapat dikatakan hal yang sulit namun juga mudah karena. novel memiliki cerita yang lebih lengkap dan rinci ketimbang cerita pendek yang jalan ceritanya lebih sederhana. Novel merupakan salah satu karya prosa yang dapat dijadikan media untuk memberikan karakter yang positif (Pusvita, 2017; Tansliova, 2018). Makna kata yang terkandung di dalamnya dapat menyiratkan fenomena sosial yang memiliki nilai positif yang bisa dijadikan alternatif sebagai contoh yang mampu mempengaruhi sikap dari seseorang. Sebuah karya. sastra berbentuk prosa dan puisi merupakan hasil pengungkapan jiwa pengarang yang dipengaruhi dari kehidupan, maupun pengalaman hidup nyata yang telah dialami maupun cerminan dari kondisi masyarakatnya. Maka dari itu untuk mempermudah peserta didik dalam memahami karya sastra terdapat materi pembelajaran apresiasi novel.

Dalam ruang lingkup karya sastra, nilai mandiri dalam suatu novel merupakan sesuatu hal yang dapat memberikan dampak tersendiri kepada pembacanya. Dengan adanya nilai mandiri akan menumbuhkan motivasi para siswa untuk bersaing secara kompetitif dalam meraih prestasinya. Mandiri juga menjadi sarana pendidikan yang berperan mempengaruhi, mendorong, mengendalikan, dan membentuk perilaku-perilaku tertentu sesuai dengan nilai-nilai yang ditanamkan, diajarkan dan diteladankan. Karena itu, perubahan perilaku seseorang, termasuk prestasinya merupakan hasil dari suatu proses pendidikan dan pembelajaran yang terencana. Mandiri sangat dibutuhkan oleh manusia dalam kehidupan sehari-hari dimanapun seseorang itu berada.

Kajian nilai mandiri dalam karya sastra telah banyak dilakukan, diantaranya dalam penelitian yang dilakukan oleh Sobari \& Wuryani (2020) pada novel "perempuan di titik nol" karya Nawal Elsaadawi, penelitian Riska (2020) pada novel "Rembulan Tenggelam di Wajahmu" karya Tere-Liye, penelitian Mikdar et al. (2021) pada Novel "Selembar Itu Berarti" karya Suryaman Amipriono dan Tantri (2017) pada novel "Tantri (Perempuan Yang Bercerita)" karya Cok Sawitri. Penelitian ini berusaha melakukan kajian nilai mandiri pada novel dengan judul Sepasang Angsa Putih Untuk Palupi Karya Marliana Kuswanti. Berdasarkan kurikulum pelajaran Bahasa Indonesia terdapat materi unsur instrinsik dan nilai-nilai kehidupan dalam novel. Alasan peneliti memilih novel Sepasang Angsa Putih Untuk Palupi Karya Marliana Kuswanti sebagai objek penelitian karena cerita dalam novel dapat memberikan inspirasi, motivasi, serta nilai-nilai positif kepada para pembacanya. Objek yang dijadikan dalam penelitian ini yaitu karya sastra yang akan digunakan di Sekolah Menengah Atas karena pada jenjang ini peserta pendidik sudah masuk usia remaja menuju dewasa. Pada usia ini masih mencari jati diri dan mecoba hal-hal baru.

Relevansi karya sastra novel terhadap nilai-nilai mandiri akan berfungsi sebagai pesan yang terkandung di dalamnya. Kemandirian sebagai suatu sikap dan perilaku yang mencerminkan kedewasaan dan rasa percaya diri dalam memecahkan setiap masalah. Membangun kesadaran diri dalam hidup mandiri patut diterapkan 
oleh semua orang. Orang tua sebagai figur di dalam rumah serta guru sebagai figur disekolah harus memberikan contoh yang baik dalam kemandirian.

Penjelasan tentang sebuah nilai, dalam penelitian ini peneliti mengkaji sebuah novel yang berjudul Sepasang Angsa Putih Untuk Palupi karya Marliana Kuswanti. Dalam novel tersebut peneliti memfokuskan pada nilai mandiri yang sangat menarik di sampaikan oleh penulis melalui gambaran hidup tokoh utama dalam cerita. Nilai mandiri merupakan suatu nilai yang menggambarkan perilaku yang tidak bergantung pada orang lain dalam menjalankan atau menyelesaikan keperluannya (Anwar, 2018). Sikap terus mencoba dan berupaya sendiri dengan kemampuan sendiri tanpa berniat mengharapkan bantuan apalagi menyusahkan orang lain. Nilai mandiri ini sangat bermanfaat bila dipetik oleh para pembaca khususnya remaja yang masih semangat dalam menggapai cita-cita dan berpengaruh positif khususnya bagi remaja yang masih memiliki jiwa bergantung pada orang lain dan tidak memiliki pendirian sendiri atau bisa dikatakan labil.

Berdasarkan latar belekang masalah di atas, penelitian ini bertujuan untuk mendeskripsikan nilai karakter mandiri tokoh dalam novel Sepasang Angsa Putih Untuk Palupi karya Marliana Kuswanti. Hasil penelitian diharapkan bermanfaat dalam penyusunan Rencana Pelaksanaan Pembelajaran (RPP) tingkat SMA.

\section{METODE PENELITIAN}

Penelitian ini menggunakan pendekatan kualitatif dengan metode deskriptif analisis. Penelitian kualitatif adalah penelitian yang bermaksud untuk memahami setiap fenomena apa yang dialami oleh subjek penelitian misalnya perilaku, persepsi, motivasi, tindakan, dan lain-lain, secara holistik dan dengan cara deskripsi dalam bentuk kata-kata dan bahasa, pada suatu konteks khusus yang alamiah dan dengan memanfaatkan berbagai metode alamiah (Moleong, 2014). Metode ini berlandaskan filsafat postpositivisme, digunakan untuk meneliti pada kondisi objek yang alamiah, yaitu intrumen penelitiannya yaitu peneliti itu sendiri atau human instrument (Sugiyono, 2015). Metode deskriptif analisis dilakukan dengan cara mendeskripsikan fakta-fakta yang kemudian disusul dengan analisis. Mula-mula data dideskripsikan, dengan maksud untuk menemukan unsur-unsurnya, kemudian dianalisis, bahkan juga diperbandingkan (Ratna, 2015). Metode deskriptif analisis ini digunakan untuk mendeskripsikan unsur-unsur dari hasil analisis dalam novel Sepasang Angsa Putih Untuk Palupi karya Marliana Kuswanti. Data terurai dalam bentuk kata-kata secara deskriptif, bukan dalam bentuk angka-angka.

Subjek yang dijadikan dalam penelitian ini yaitu novel Sepasang Angsa Putih Untuk Palupi karya Marliana Kuswanti. Novel Sepasang Angsa Putih Untuk Palupi karya Marliana Kuswanti cetakan pertama yang diterbitkan oleh Bhuana Sastra (Imprint dari Penerbit Bhuana Ilmu Populer) pada tahun 2017. ISBN 978-602-394-890-1. Tebal buku $236 \mathrm{hlm}$. Objek yang dijadikan dalam penelitian ini yaitu unsur intrinsik dan nilai mandiri yang terdapat dalam novel Sepasang Angsa Putih Untuk Palupi karya Marliana Kuswanti.

Dalam pendekatan kualitatif instrument yang digunakan yaitu berupa pedoman analisis sebagai cara untuk membantu peneliti dalam menganalisis. Berikut ini terdapat dua pedoman analisis yang digunakan yaitu, pedoman analisis unsur instrinsik dan pedoman analisis nilai mandiri. Data yang diperoleh dalam penelitian ini yaitu, data primer dan data sekunder. Data primer yaitu novel Sepasang Angsa Putih Untuk Palupi karya Marliana Kuswanti. Sedangkan, data sekunder dalam penelitian ini, peneliti mengumpulkan beberapa data dan sumber data meliputi buku bacaan, artikel/jurnal yang terkait dengan teori sastra dan nilai disiplin yang relevan dengan objek yang diteliti.

Teknik pengumpulan data dilakukan dengan cara menentukan sumber data yang akan diteliti yaitu novel Sepasang Angsa Putih Untuk Palupi karya Marliana Kuswanti, melakukan pembacaan awal dengan cermat keseluruhan novel, lalu menentukan judul penelitian, menentukan fokus permasalahan, melakukan penandaan pada novel yang berfokus pada penelitian, dan mendeskripsikan semua data yang diperoleh dari teknik pengumpulan data. Teknik analisis data yang digunakan menggunakan analisis deskripsi kualitatif, dengan tujuan pengkajian dan pendeskripsian permasalahan yang diteliti. Menurut Bongdan dan Biklen (dalam Syamsudin, 2015: 110) analisis data adalah proses pelacakan dan pengaturan sistematis catatan lapangan dan bahan-bahan lain yang dikumpulkan untuk meningkatkan pemahaman terhadap bahan-bahan 
lain yang dikumpulkan untuk meningkatkan pemahaman terhadap bahan-bahan tersebut agar dipresentasikan semuanya kepada orang lain. Teknik ini digunakan karena jenis penelitian ini tidak dapat diperoleh dengan menggunakan prosedur-prosedur statistik atau dengan cara lain dari kuantitatif (pengukuran), karena data yang akan diteliti berupa kalimat yang merupakan data kualitatif serta memerlukan penjelasan deskripsi. Penelitian ini mendeskripsikan apa yang menjadi masalah, kemudian menganalisis dan menafsirkan data yang ada. Metode analisis isi yang digunakan untuk menelaah isi dari suatu dokumen, dalam penelitian ini yang dimaksud adalah novel Sepasang Angsa Putih Untuk Palupi karya Marliana Kuswanti.

\section{HASIL DAN PEMBAHASAN}

Dalam novel Sepasang Angsa Putih Untuk Palupi karya Marliana Kuswanti ini mengisahkan seorang tokoh yang bernama Palupi. Ia seorang anak perempuan yang ditentang keras oleh bapak kandungnya dalam mengejar cita-citanya sebagai seorang penulis. Palupi anak ke empat dari empat bersaudara. Kakak-kakak kandung Palupi yang bernama Mas Heru, Mbak Siwi, dan Mas Ganjar sudah sukses dan berumah tangga. Namun dalam keluarga besar, hanya ibu Palupi yang mendukung dan meridhoi tentang keputusan Palupi untuk menjadi seorang penulis.

A. Deskripsi Dan Pembahasan Hasil Data Penelitian

1. Unsur Intrinsik

Sebuah novel memiliki unsur-unsur pembangun yang saling berkaitan, salah satunya unsur instrinsik. Unsur-unsur intrinsik yang dibahas dalam penelitian ini diantaranya adalah tema dan plot. Tema merupakan dasar cerita, atau gagasan umum dala sebuah karya sastra. Tema mayor dalam novel Sepasang Angsa Putih Untuk Palupi karya Marliana Kuswanti adalah perjuangan. Dalam karya tersebut sebuah perjuangan selalu dihadapkan oleh tokoh utama yaitu, Palupi. Perjuangan yang ia hadapi dalam hidupnya selalu penuh rintangan dan kejutan yang membuat dirinya jatuh bangun hingga hampir putus asa. Perjuangan ini berawal dari sebuah perbedaan pendapat antara seorang anak dan bapak. Keduanya yang sulit mengalah dan menahan ego masingmasing hingga menjadikan Palupi pergi meninggalkan rumah dan titik perjuangan itulah dimulai. Ketika pemahaman di tentang, ketika prinsip dilarang, Palupi semakin nekad untuk memperjuangkan hak dan citacitanya dalam melanjutkan hidup. Sekalipun ia harus siap di usir dari rumah asal tempat tinggalnya. Dapat dibuktikan dalam kutipan berikut.

"Upi akan terus menulis cerita pendek dan bersambung untuk koran dan majalah. Mudab-mudahan dimuat dan honornya lumayan. Upi yakin, kalau memang ini sudah saatnya rezeki Upi mengalir melalui tangan Bapak. terhenti, Tuban pasti akan membukakan jalan rezeki untuk Upi. Upi tidak akan terlantar" (Kuswanti, 2017:11)

Adapun tema minor atau tema tambahan pada novel Sepasang Angsa Putih Untuk Palupi Karya Marliana Kuswanti adalah perbedaan prinsip orang tua. Hal tersebut dapat dilihat dari kutipan beriku ini

"Lagi pula, memang Upi tak ingin jadi karyawan atau kerja kantoran, Bu. Palupi ingin kerja lepas, jadi penulis profesional. Walaupun Upi belum bisa bangun rumah gedongan atau punya tabungan milyaran, setidaknya dari empat anak Bapak, cuma Palupi yang sejak, kuliah sudah bisa dapat uang sendiri meski tak pasti dari honor cerita yang Upi kirim ke majalah atau koran. Memang uang itu belum cukup untuk makan sebulan, Cuma buat beli pulsa atau satu dua buku kuliah. Tapi Mas Heru, Mbak. Siwi, Mas Ganjar, semuanya banya mengandalkan uang saku dari Bapak. seratus persen!” (Kuswanti, 2017:10)

Pada kutipan diatas dapat ditarik kesimpulan bahwa Palupi kerap sering ada masalah dan perdebatan dengan bapaknya yang selalu berbeda prinsip. Palupi yang memiliki harapan ingin menjadi kerja lepas sebagai penulis profesional tak sejalan dengan harapan bapaknya yang menginginkan semua anaknya termasuk Palupi sebagai PNS.

Alur dalam novel Sepasang Angsa Putih Untuk Palupi karya Marliana Kuswanti menggunakan alur mundur, yaitu peristiwa yang dikisahkan bersifat perputaran waktu atau flashback. Dikatakan alur mundur pada novel ini karena pengarang bermula menjelaskan kejadian yang telah terjadi di masa lalu dan dtuangkan kembali menjadi cerita yang dijadikan sebagai kenangan si tokoh utama. Berikut bukti kutipannya. 
"Mei masih sama. Itu cerita kemarin. Tapi kemarin adalah sepulub tabun yang lalu. Bukankah tak pernah ada

kata lama untuk setiap kenangan yang begitu membekas?” (Kuswanti, 2017:13).

Dalam kutipan novel di atas terbukti bahwa alur yang digambarkan oleh pengaran adalah alur mundur. Yaitu jalan cerita yang dikisahkan untuk mengulas kembali yang pernah terjadi di masa lampau. Cerita yang membuat tokoh utama membuka kenangan masa lalu dengan berbagai konflik dan lika liku perjalanan ceritanya. Hingga akhirnya cerita berlanjut pada akhir perjuangan tokoh utama dalam menggapai cita-citanya.

\section{Tokoh Penokohan}

Tokoh dan penokohan pada novel Sepasang angsa putih untuk Palupi karya tulis Marliana kuswanti meliputi tokoh utama dan tokoh tambahan. tokoh utama ialah tokoh yang memiliki peranan sangat penting di dalam novel tokoh utama dalam novel ini adalah Palupi, karena tokoh tersebut mempunyai peran yang sangat penting dalam cerita dan juga menentukan gerak tokoh yang lain, sedangkan tokoh tokoh tambahan dalam novel ini adalah Bapak Palupi, Ibu Palupi, Mas Ganjar, Mbak Siwi, Mas Heru, Bonita, Santi, Sarmila, dan Ken. Penulisan tokoh-tokoh dalam novel tersebut ada yang diceritakan langsung oleh penulis maupun berdasarkan dialog dialog antar tokoh.

Sebagai tokoh utama, kehadiran Palupi selalu muncul dari awal cerita hingga akhir cerita. Palupi digambarkan sebagai seorang anak perempuan yang sangat gigih dan berani mempertahankan cita-citanya yaitu menjadi penulis. sebagai seorang anak, ia ingin membuktikan kepada orang tuanya untuk menjadi orang yang sukses dalam bidang yang yang di kuasainya salah satunya adalah menulis. Bagi Palupi tidak ada satu orang pun yang bisa melarang dirinya untuk mengejar cita-citanya sebagai penulis termasuk bapaknya. Palupi juga digambarkan sebagai orang yang sangat sabar dan pasrah juga mandiri dalam menghadapi berbagai masalah yang menimpanya.

Tokoh yang kedua adalah Bapak Palupi, bapak Palupi adalah tokoh yang selalu menentang keras keinginan tokoh utama yaitu Palupi watak Bapak Palupi adalah seseorang yang egois, disiplin dalam waktu dan menilai suatu pekerjaan hanya dari segi materi atau jumlah pendapatan penghasilan. Bapak Palupi tidak pernah sejalan prinsip dan juga pemikirannya dengan anak bungsunya ini.Karena tokoh Bapak Palupi tidak mendukung jalan cerita dan tidak pernah menyetujui keputusan Palupi untuk menjadi seorang penulis semua hal yang dilakukan Bapak Palupi pada Palupi merupakan hal yang sangat tidak wajar antara orang tua dengan anak. Bapak Palupi merupakan tokoh yang sangat keras kepala la la dalam Memegang teguh pendiriannya itu sebabnya Bapak Palupi tidak menyetujui keinginan Palupi untuk menjadi penulis terkenal. Untuk ciri fisik tokoh Bapak Palupi, pengarang tidak menggambarkannya secara langsung. pengarang hanya menjelaskan kehidupan sosial yang dialami oleh tokoh Bapak Palupi dan sebagai apa dalam lingkungannya.

Tokoh ketiga adalah Ibu Palupi. Ibu Palupi merupakan orang tua kandung Palupi yang memiliki watak berbeda dengan bapak Palupi. Ibu Palupi merupakan tokoh yang sabar dan penyayang terhadap suami dan anaknya. Ibu Palupi berbeda dengan bapak Palupi yang selalu menentang keinginan Palupi. Ibu Palupi selalu setuju dengan keinginan Palupi sebagai penulis. Bahkan Ibu Palupi senang bila Palupi semangat mengejar cita-cita baiknya itu. Ibu Palupi sangat suka dengan hasil karya tulisan Palupi. Pengarang juga menceritakan tokoh Ibu Palupi sebagai tokoh seorang ibu yang selalu mengkhawatirkan anaknya nya ketika jauh. Ibu Palupi tokoh yang sangat lembut dan sabar dalam menghadapi watak suami dan anaknya yang selalu berbeda pendapat. namun naluri seorang ibu sangat kuat yang tak bisa tinggal jauh dengan anaknya walau untuk mengejar cita-citanya. Namun dengan berat hati ibu Palupi mengikhlaskan kepergian Palupi untuk merantau ke kota lain demi mengejar cita-citanya. dalam novel Sepasang angsa putih untuk Palupi menggambarkan tokoh Ibu Palupi tidak pernah bertentangan dengan tokoh utama. Pengarang menggambarkan sosok Ibu Palupi yang sangat dekat dengan anaknya yaitu Palupi.

Tokoh keempat adalah Sarmilah. Tokoh Sarmilah digambarkan sebagai tokoh wanita yang sangat keras dan tegas. Tokoh sarmilah di dalam cerita adalah pemilik kios pulsa di Jakarta yang dijuluki sebagai juragan gerobak untuk disewakan. Tokoh utama yaitu Palupi, menjadi karyawan kios pulsa Sarmilah. Pengarang menggambarkan tokoh sarmilah sebagai wanita yang kurang ramah pada setiap lawan bicaranya. Sarmilah adalah tokoh yang kurang ramah terhadap lawan bicaranya. Namun dibalik sifatnya yang seperti itu 
ia tetap baik dan peduli terhadap karyawannya yaitu Palupi. Ia masih sempat memberikan makan siang untuk Palupi walau menawarkan makan nya dengan tegas tanpa basa basi.

Untuk ciri fisik Sarmilah, pengarang menggambarkan sebagai wanita yang bertubuh besar.

Tokoh kelima adalah Bonita. Tokoh Bonita digambarkan sebagai tokoh wankita yang baik, perhatian, dan bertanggung jawab. Bonita merupakan teman kos tokoh utama yaitu Palupi yang memiliki kesamaan dengan palupi yakni merantau ke Jakarta untuk melanjutkan hidupnya. Di dalam cerita, pengarang menjelaskan bahwa Bonita merupakan pekerja buruh yang sangat bertanggung jawab dan pengarang menggambarkan watak Bonita.

Tokoh keenam adalah Santi. Tokoh Santi digambarkan sebagai tokoh wanita yang perhatian dan baik sesama temannya. Santi merupakan teman kos Palupi dan juga Bonita yang sama merantau ke Jakarta dan bekerja sebagai SPG wanita. Tokoh Santi memang digambarkan adalah tokoh yang protagonist sebab ia sangat baik dan perhatian kepada siapapun. Namun, walau santi baik tetapi dimata warga sekitar kos-kosan yang mereka tinggal Santi kerap mendapatkan cibiran dari warga disana. Namun di akhir cerita, pengarang menceritakan bahwa tokoh Santi akhirnya menimggal dunia akibat kecelakaan.

Tokoh ketujuh adalah Mas Heru. Tokoh Mas Heru digambarkan sebagai tokoh yang sangat tegas dan keras. Di dalam cerita digambarkan tokoh Mas heru ini adalah sosok anak yang sangat nurut dengan orangtuanya. Namun keras terhadap adiknya yaitu Palupi selaku tokoh utama. Mas Heru memiliki sifat yang sangat penyayang dan penurut kepada orangtuanya. Namun sangat keras dan tegas terhadap adiknya.

Tokoh berikutnya ada Mbak Siwi dan Mas Ganjar. Di dalam cerita, tidak ada percakapan dialog kedua tokoh tersebut. Namun, pada beberapa bagian cerita, pengarang terkadang menyebut kedua nama tokoh tersebut. Tokoh tambahan yang bernama Mbak Siwi dan Mas Ganjar. Kedua tokoh tersebut tidak muncul didalam sebuah dialog, namun pengarang selalu memperkenalkan melalui percakapan tidak langsung yang disampaikan oleh tokoh utama. Untuk watak tokoh Mbak Siwi dan Mas Ganjar ini digambarkan sebagai tokoh yang penurut. Dijelaskan jelas dalam cerita tersebut bahwa tokoh Mbak Siwi dan Mas Ganjar ini selalu tunduk dan patuh jika diatur hidupnya oleh bapaknya.

Tokoh berikutnya adalah Ken. Tokoh Ken digambarkan sebagai orang yang ramah dan sangat menghargai lawan bicaranya apalagi wanita. Di dalam cerita, pengarang memuncul tokoh Ken sebagai tokoh tambahan. Tokoh Ken memiliki sifat yang sopan dan ramah. Pengarang juga menggambarkan fisik Ken dibagian cerita ini.

\section{Latar}

Dalam novel ini latar yang dibahas adalah, latar tempat, waktu dan sosial-budaya. Latar Dalam novel ini latar tempat diantaranya adalah teras rumah Palupi, Jakarta, kios pulsa, kos-kosan, makam dan Yogyakarta. Teras rumah Palupi menjadi gambaran awal pembuka cerita yang ada di dalam novel tersebut. Latar tempat Jakarta merupakan kota yang dipilih Palupi sebagia tempat untuk merantau. Latar tempat Kios pulsa terletak di kota Jakarta. Kebetulan tokoh utama yaitu Palupi sedang mencari pekerjaan dan pemilik kios tersebut bersamaan sedang mencari seorang pegawai wanita. Latar tempat berikutnya yaitu Kos-kosan di Jakarta. Koskosan ini menjadi tempat tidur sementara Palupi di Jakarta selama merantau. Tidak berharap tempat yang mewah, asalkan nyaman dan bisa tetap mengerjakan hobinya yaitu membuat naskah cerita. Latar selanjutnya yaitu Makam. Pengarang mengganbarkan latar makan tersebut diletakkan diakhir cerita. Dalam novel tersebut diceritakan, tokoh Palupi yang telah kembali ke rumah orangtuanya. Tempat makam menjadi tempat terakhir Palupi bertemu dengan bapaknya yang telah tiada. Hampir sepuluh tahun Palupi sudah tidak bertemu bapak semenjak ia memutuskan untuk pergi ke Jakarta setelah perdebatan kala itu dengan bapaknya. Latar tempat Kota Yogyakarta merupakan kampung halaman rumah orang tua Palupi. Sebelum merantau, Palupi sempat tinggal dengan orangtua nya di kota Yogyakarta. Di dalam cerita novel tersebut latar tempat Yogyakarta disebutkan di akhir cerita ketika tokoh utama yaitu Palupi pulang ke kampung halamannya.

Latar waktu yang terjadi dalam novel Sepasang Angsa Putih Untuk Palupi Karya Marliana Kuswanti adalah waktu pagi hari dan jam 12 Malam. Hampir setiap bagian novel, kejadian cerita di gambarkan suasana pada pagi hari. Pengarang membagikan cerita hampir setiap bagian novel menggambarkan suasana pagi hari. Tokoh Palupi yang kerja di kios pulsa pun selalu di ceritakan pada pagi hari, suasana kos-kosan tempat Palupi 
tinggal merantau di Jakarta pun sellau diceritkan pada pagi hari. Selain latar waktu pagi hari, ada juga latar waktu malam hari yaitu tepatnya pukul 12 malam. Di dalam cerita digambarkan suasana jam 12 malam yang disampaikan sebanyak dua kali oleh pengarang.

Adapun latar sosial-budaya merupakan penggambaran yang merujuk pada hal-hal yang berhubungan dengan perilaku kehidupan sosial masyarakat disuatu tempat yang disampaikan pada cerita karya sastra. Dalam cerita pada novel Sepasang Angsa Putih Untuk Palupi Karya Marliana Kuswanti, latar sosial-budaya yang digambarkan oleh pengarang salah satunya terkait tentang kebiasaan atau suatu peraturan yang ada di dalam keluarga Palupi. Bapak Palupi memiliki prinsip atau peraturan kepada anaknya untuk mewajibkan anaknya bekerja sebagai PNS. Bapak Palupi menganggap tidak ada pekerjaan lain yang lebih baik selain PNS. Bahkan Bapak Palupi menghargai anaknya yang berbulan-bulan menganggur demi mengejar cita-citanya sebagai PNS daripada memiliki anak yang pekerja keras tetapi bukan sebagai PNS seperti yang Bapak Palupi inginkan. Di samping itu ada latar soial-budaya oleh pengarang yaitu tentang adat kebiasaan masyarakat yang terjadi dilingkungan sekitar kos-kosan di Jakarta. Kos-kosan ini tempat Palupi, Santi dan Bonita tinggal. Kebiasaan suasana bermasyarakat disana bisa dibilang kurang sehat dan kurang nyaman. Masyarakat disana lebih masa bodo dan kurangnya toleransi antarsesama warga.

4. Sudut Pandang

Dalam memahami setiap peristiwa pengarang harus menentukan sudut pandang yang tepat. Hal ini bertujuan supaya cerita yang ditulis terasa pas dan sampai kepada pembaca. Dalam novel Sepasang Angsa Putih Untuk Palupi Karya Marliana Kuswanti, pengarang menggunakan sudut pandang orang ketiga "Dia" Mahatahu. Dalam hal ini pengarang mampu menceritakan semua sesuatu baik yang bersifat fisik, dapat diindera, maupun sesuatu yang hanya terjadi dalam hati dan pikiran tokoh. Pengarang juga mampu mengomentari dan menilai secara bebas seolah-olah tidak ada satu rahasiapun tentang tokoh yang tidak diketahuinya.

5. Gaya Bahasa

Dalam sebuah karya sastra, pengarang menggunakan gaya bahasa sebagai bentuk imaji dalam menyampaikan sebuah cerita. Gaya bahasa dalam novel Sepasang Angsa Putih Untuk Palupi Karya Marliana Kuswanti terdapat majas simile, majas personifikasi, majas hiperbola dan majas sinestesia.

6. Amanat

Dalam sebuah karya sastra salah satunya novel pasti selalu ada pesan yang dapat dipetik dalam sebuah cerita atau peristiwa yang telah disampaikan oleh pengarang. Suatu karya sastra tidak hanya asal diciptakan sebagai alat penghibur saja melainkan harus berisi pesan yang dapat tersampaikan oleh pembaca dan berharap dapat dijadikan pelajaran dalam kehidupan sehari-hari. Amanat yang terdapat dalam novel Sepasang Angsa Putih Untuk Palupi karya Marliana Kuswanti salah satunya yaitu apabila kita marah, kecewa bahkan sakit hati yang teramat dalam karena sikap salah satu anggota keluarga, tetapi mereka tetap keluarga. Seseorang yang bahagia dengan karir nya yang sudah sukses, tetapi kehadiran keluarga tetap menjadi pelengkap kebahagian. Karena harta yang paling berharga dan tak dapat tergantikan oleh apapun yaitu keluarga.

B. Analisis Nilai Mandiri Pada Novel Sepasang Angsa Putih Untuk Palupi karya Marliana Kuswanti

Dalam sebuah karya sastra salah satunya Novel, pasti mengandung nilai-nilai kehidupan di dalam cerita. Salah satunya yaitu nilai mandiri. Nilai mandiri sangatlah harus di terapkan dan dimiliki oleh setiap orang salah satunya peserta didik dalam menjalankan hidupnya baik di dalam lingkungan sekolah maupun diluar sekolah. Nilai-nilai mandiri dalam novel Sepasang Angsa Putih Untuk Palupi karya Marliana Kuswanti yakni nilai kemandirian emosi, nilai kemandirian ekonomi, nilai kemandirian intelektual, dan nilai kemandirian sosial.

Kemandirian emosi merupakan kemmapuan dapat mengontrol emosi dengan baik dan tidak tergantung pada oranglain. Nilai kemandirian emosi ini sangat penting diterapkan oleh para peserta didik yang masih banyak dikatakan labil dalam mengolah emosi dan pikirannya. Adapun analisis nilai mandiri emosi dalam novel Sepasang Angsa Putih Untuk Palupi karya Marliana Kuswanti adalah sebagai berikut

'Pak, salah Upi apa, Pak? Upi bukan orang malas, Pak. Upi bangun tak kalah pagi dari kebanyakan orang. Upi babkean kerap terjaga saat orang-orang diluar sana, termasuk. Bapak, sudah terlelap berjam-jam. Upi juga 
berusaha cari uang biar bisa mandiri dan tak jadi tanggungan Bapak. lagi. Tapi cari uang tak harus dengan melamar kerja di perusahaan-perusahaan atau antre pendaftaran PNS, kan, Pak?" Palupi bicara tegas tapi tak. keras. Napasnya tersengal oleh debur gelombang di hatinya dan itu membuat suaranya parau." (Kuswanti, 2017: 7)

Pada kutipan diatas, digambarkan seorang tokoh utama bernama Palupi mencoba mengontrol emosinya dengan menjelaskan semua keluhan yang ia rasakan terhadap prinsip bapaknya yang selama ini membuat Palupi merasa terkekang. Kemandirian emosi yang dilakukan oleh Palupi salah satunya ia masih mampu menjelaskan dalam keadaan hati yang kecewa namun masih sadar dan mampu untuk mengontrol emosi dengan cara berbicara tegas namun tidak menggunakan intonasi nada yang tinggi. Hal ini perlu dicontoh oleh peserta didik karena etika berbicara kepada oranglain terlebih lagi orang yang umurnya sudah tua haruslah tetap menggunakan tutur kata yang baik dan tidak menggunakan intonasi nada yang tinggi.

"Orang dewasa belajar mengatasi perpisahan tampa air mata. Jika bukan sebagai pasangan, mereka masih bisa menjadi kawan. Tidak mudah memang, yang pesimis pun pasti menyebutnya serupa impian Palupi menjadi penulis profesional, omong kosong. Tapi orang dewasa menghadapi jauh lebih banyak. lagi masalah yang tak mudah untuk. diatasi. Jadi, kalau soal cinta, tak usah diperumit." (Kuswanti, 2017: 152-153)

Dalam kutipan diatas, digambarkan seorang tokoh bernama Palupi yang mencoba mengikhlaskan sesuatu yang bukan menjadi miliknya. Nilai kemandirian emosi yang dapat dipetik adalah, sebagai manusia tidak perlu menyimpan dendam hanya karena sebuah suatu hal yang tidak bisa dipaksakan. Berpikir secara bijak dan menahan diri untuk ikhlas jauh lebih baik karena setiap masalah tidak harus dihadapi dengan air mata.

Nilai kemandirian ekonomi yaitu kemampuan mengatur ekonomi secara mandiri tanpa tergantung kepada ekonomi oranglain. Nilai kemandirian ekonomi ini sangat penting diterapkan oleh para peserta didik di masa depan. Jika sejak dini nilai ini sudah diterapkan, maka para peserta didik akan mampu menghadapi masalah ekonominya di masa yang akan datang. Karena tidak selamanya setiap anak hidup harus bergantung pada orangtuanya. Harus mampu menentukan pilihannya sendiri dan mampu bertanggung jawab lahir batin hidunya sendiri. Dalam novel Sepasang Angsa Putih Untuk Palupi karya Marliana Kuswanti berikut analisis nilai kemandirian ekonomi

"Peribal rencananya mencari kontrakan, tak. lagi tinggal di dalam kios, itu karena Palupi pikir hidupnya harus mengalami peningkatan taraf kesejahteraan dari waktu ke waktu meski lambat. Ia ingin mengukur kemampuan finansialnya dengan melepaskan diri dari belas kasiban Sarmilah yang selama ini menampunya; menyediakan listrik, gratis, air gratis, dan makan minum. Palupi tak ingin lengah, mengira keuangannya sebagai penulis sudah aman padahal sebenarnya itu karena ia tak pernah berhadapan langsung dengan tuntutan mambayar ini itu." (Kuswanti, 2017: 126)

Pada kutipan diatas merupakan salah satu bentuk nilai mandiri secara ekonomi. Tokoh utama bernama Palupi ini menyadari bahwa tak ingin lagi merepotkan oranglain salah satunya Sarmilah yang selama ini sudah banyak membantu nya selama merantau di Jakarta. Palupi ingin bertanggung jawab dan mandiri secara finansial terhadap hidupnya.

"Palupi mengukur perkembangan karir dan kondisi kenangannya. Selepas Sarmilah mendapatkan penjaga kios pengganti, otomatis Palupi fokus hanya pada menulis. Jadi ia harus cermat berhitung dan memikirkan strategi untuk mencegah keuangannya terpuruk oleh royalti satu dua buku yang bisa saja anjlok sewaktu-waktu dan paceklik. pemuatan tulisan di media cetak." (Kuswanti, 2017: 179)

Pada kutipan diatas merupakan salah satu bentuk nilai mandiri secara ekonomi. Tokoh Palupi sadar dan berpikir keras untuk memikirkan secara matang dan cermat perihal finansialnya. Seseorang yang sudah menerapkan nilai mandiri dalam hal ekonomi akan mampu menahan diri untuk tidak boros dan dengan sengaja menghambur-hamburkan uang hanya untuk kesenangan sesaat. Seseorang yang sudah mandiri dalam hal ekonomi akan selalu merancang berbagai strategi supaya tetap hidup dan bertahan dalam menjalanan hidupnya saat ini, esok dan selamanya.

Nilai kemandirian intelektual merupakan kemampuan seseorang untuk mengatasi setiap permasalah yang sedang dihadapi. Adapun analisis nilai kemandirian intelektual dalam novel Sepasang Angsa Putih Untuk Palupi karya Marliana Kuswanti sebagai berikut 
"Tika kemudian terlihat tak susah itu karena memang Palupi tak ingin menjadikannya susah, tak ingin mempertontonkan kesusabannya itu sebab baginya kesusahannya memang bukan suatu pertunjukan yang apik untuk dibeberkan kepada semua orang. Meski bila perempuan muda lain yang terjebak pada situasi Upi, tanpa iman cukup dan mental yang dikuat-kuatkan, bukan tidak mungkin dengan begitu mudah terjebak pada prostitusi, narkoba atau segala yang buruk-buruk, tapi cepat mendatangkan uang." (Kuswanti, 2017: 65)

Pada kutipan diatas, sikap tokoh Palupi sudah mencerminkan nilai kemandirian dalam intelektual. Ia dapat berpikir dewasa dan dapat secara mandiri menyelesaikan permasalahannya sendiri tanpa harus cerita atau meminta bantuan atau bahkan belas kasihan terhadap oranglain. Memang tidak semua orang punya prinsip dan sikap yang sama seperti Palupi, tapi setiap orang dapat mencoba belajar menjadi pribadi yang lebih mandiri dalam menghadapi masalah pribadi tanpa harus dibeberkan kepada oranglain.

Nilai kemandirian sosial merupakan kemampuan seseorang dalam hal mengadakan interaksi terhadap oranglain dan tidak tergantung pada aksi oranglain. Analisis nilai kemandirian sosial pada novel Sepasang Angsa Putih Untuk Palupi karya Marliana Kuswanti sebagai berikut

"Yang lebih menjadi masalab bagi Palupi dan harus segera ia tangani adalah masa-masa ketika honor tulisannya mengalami paceklik. Hidup di rantau sungguh-sungguh mengujinya. Ibunya tak pernah alpa mengirim uang jajan, tapi bukan itu yang ia barapkan. Palupi ingin mandiri, benar-benar sepenubnya makan, minum, dan membayar segala kebutuhannya dengan hasil keringatnya sendiri. Palupi dapat membayangkan, cepat atau lambat, bapaknya yang keras itu juga akan tabu kalau ibunya rajin mengiriminya uang jajan secara sembunyi-sembunyi dengan menilap jatab belanja." (Kuswanti, 2017: 41-42)

Pada kutipan tersebut merupakan salah satu nilai kemandirian sosial yang diterapkan oleh tokoh utama yaitu Palupi. Palupi menyadari bahwa tak ingin selamanya merepotkan ibunya yang setiap bulan selalu mengirimkannya uang walau itu hasil dari melipat uang jatah bulanan yang dikasih dari Bapak. Walau manusia hidup secara bersosial, namun Palupi sangat berat hati jika terus membuat ibunya turut melakukan kesalahan dengan cara mengirimkan uang untuknya secara diam-diam dibelakang bapak. Palupi hanya tidak ingin nantinya menjadi masalah baru yang akan membuat masalah menjadi lebih rumit.

Hasil analisis unsur intrinsik pada novel Sepasang Angsa Putih Untuk Palupi Karya Marliana Kuswanti menggunakan alur mundur. Hal yang sama juga ditemukan dalam kajian intrinsik pada penelitian yang dilakukan Sobari \& Wuryani (2020), Riska (2020), Mikdar et al. (2021) dan Tantri (2017). Dalam penelitian ini terdapat lima tahap alur, yaitu tahap penyituasian, tahap pemunculan konflik, tahap peningkatan konflik, tahap klimaks, dan tahap penyelesaian. Karakter yang terdapat dalam novel Sepasang Angsa Putih Untuk Palupi Karya Marliana Kuswanti yaitu, Palupi digambarkan sebagai tokoh yang baik, keras kepala dan pekerja keras. Bapak Palupi digambarkan sebagai tokoh yang keras kepala dan terlalu sering mengatur serta mengekang setiap kehidupan anaknya. Ibu Palupi, digambarkan sebagai tokoh wanita yang lembut, baik hati dan pengertian terhadap anak-anaknya. Di samping itu, ada tokoh Sarmilah, Bonita, Santi, Mas Heru, Mbak Siwi dan Mas Ganjar, serta Ken Latar yang terdapat dalam novel ini menggunakan latar tempat, latar waktu dan latar sosial-budaya. Latar tempat meliputi, Teras rumah Palupi, Kos-kosan, Kios pulsa, makam, Jakarta, dan Yogyakarta. Latar waktu meliputi, pagi hari dan jam 12 malam. Latar sosial-budaya meliputi, adat kebiasaan peraturan keluarga Palupi yang dibuat oleh Bapak Palupi, gambaran kebiasaan masyarakat sekitar kos-kosan yang selalu membuat kegaduhan dan kurangnya rasa toleransi yang tinggi terhadap sesama.

\section{KESIMPULAN}

Nilai karakter mandiri pada novel Sepasang Angsa Putih Untuk Palupi Karya Marliana Kuswanti yaitu nilai karkater mandiri pada tokoh yang ada di novel tersebut. Nilai mandiri tersebut terdapat empat macam, yaitu kemandirian emosi, kemandirian ekonomi, kemandirian intelektual, dan kemandirian sosial. Hasil dari penelitian ini dijadikan relevansi sebagai susunan Rencana Pelaksanaan Pembelajaran (RPP) yang disesuaikan dengan Kurikukum 2013 yaitu pada Kompetensi Dasar (KD) 3.20 menganalisis pesan dari dua buku fiksi (novel dan kumpulan puisi) yang dibaca. Dengan dibuatnya Rencana Pelaksanaan Pembelajaran (RPP) diharapkan guru mendapat alternatif dalam materi pembelajaran analisis novel yang dibaca. 


\section{DAFTAR PUSTAKA}

Anwar, H. (2018). Mengembangkan Sikap Kemandirian Melalui Pendidikan Boarding School Di Madrasah Tsanawiyah Hubulo Kecamatan Tapa Kabupaten Bone Bolango. Irfani, 14(1), 61-76.

Baron, R. (2020). Nilai kecantikan perempuan dalam puisi aminah karya WS Rendra. Jurnal Metamorfosa, 8(1), 37-51.

Djuanda, D. (2014). Pembelajaran sastra di SD dalam gamitan Kurikulum 2013. Mimbar Sekolah Dasar, 1(2), 191-200.

Fitrianingrum, E. (2016). Nilai Budaya dalam Cerita Batu Darah Muning dari Kecamatan Serawai Kabupaten Sintang. JP-BSI (Jumal Pendidikan Bahasa dan Sastra Indonesia), 1(2), 45-57.

Kusuma, E. R. (2018). karakteristik novel senja di jakarta karya mochtar lubis sebagai alasan pengembangan bahan pembelajaran sastra di sekolah. In Prosiding Seminar Nasional Babasa dan Sastra Indonesia (SENASBASA) (Vol. 1, No. 1).

Kuswanti, M. (2017). Sepasang Angsa Putib Untuk Palupi. Jakarta: Bhuana Sastra.

Mikdar, M. Q., Nurhasanah, E., \& Hartati, D. (2021). Kajian Nilai Mandiri Novel Selembar Itu Berarti Karya Suryaman Amipriono. Basindo: jurnal kajian bahasa, sastra Indonesia, dan pembelajarannya, 5(2), 259-275.

Moleong, L. (2014). Metode Penelitian Kualitatif. Bandung: PT. Remaja Rosdakarya.

Ratna, N. (2015). Teori, Metode dan Teknik Penelitian Satra. Yogyakarta: Pustaka Pelajar.

Pusvita, W. D. (2017). Character Education Values In'ayah'novel By Andrea Hirata (Nilai-Nilai Pendidikan Karakter Pada Novel'ayah'karya Andrea Hirata). Leksema: Jurnal Babasa dan Sastra, 2(1), 51-63.

Riska, A. R. (2020). Analisis Unsur Intrinsik Novel Rembulan Tenggelam di Wajahmu Karya Tere-Liye. Parole Jurnal Pendidikan Bahasa dan Sastra Indonesia), 3(3), 515-522.

Sobari, T., \& Wuryani, W. (2020). Analisis intrinsik pada novel "perempuan di titik nol" karya nawal elsaadawi. Parole (Jurnal Pendidikan Bahasa dan Sastra Indonesia), 3(4), 901-908.

Sugiyono. (2017). Metode Penelitian Kuantitatif, Kualitatif, dan R\&d. Bandung: Alfabeta.

Sukirman, S. (2021). Karya Sastra Media Pendidikan Karakter bagi Peserta Didik. Jurnal Konsepsi, 10(1), 17-27.

Susilo, P., Nugroho, A., \& Sari, I. P. (2021). Analisis Nilai Moral Novel Kembara Karya Pradana Boy ZTF. LITER ATUR: Jurnal Bahasa, Sastra dan Pengajaran, 1(2), 93-102.

Tansliova, L. (2018). Nilai-nilai karakter bangsa pada novel "ranah 3 warna" dan "rantau 1 muara" karya ahmad fuadi serta kontribusinya terhadap pendidikan karakter. Genta Mulia: Jurnal Ilmiah Pendidikan, 9(2).

Tantri, A. A. S. (2017). Nilai-Nilai Pendidikan Karakter Dalam Novel Tantri (Perempuan Yang Bercerita) Karya Cok Sawitri Sebagai Alternatif Pembelajaran Sastra Di Sekolah Dasar. In Proceedings Education and Language International Conference (Vol. 1, No. 1).

Wicaksono, A. (2017). Pengkajian prosa fiksi (Edisi revisi). Garudhawaca. 